\title{
Shared Space in Conflict Areas: Exploring the Case of Nicosia's Buffer Zone
}

\author{
By Zinovia Foka*
}

The physical divide of urban areas, often the extreme result of conflict and state contestation is considered a non-sustainable longterm solution. However, a political settlement of the conflict is, in most cases, considered a prerequisite for cooperative development. Thus, where consensus remains unachievable, this temporary situation is becoming permanent, affecting the city's physical landscape, and penetrating various levels of urban life. Towards the goal of exploring the broader questions of emergence of this type of city as a norm and its viability, the city of Nicosia provides an apt framework for a case study. Officially divided since 1974 between Turkish-and Greek-Cypriots, this city demonstrates an elaborate Master Plan facilitating professional collaboration between opposing parties. Furthermore, during the last decade, Nicosia has been experiencing a shift of paradigm mainly due to the restitution of mobility between its two sectors in 2003. This paper is looking at local initiatives in Nicosia's urban core, the Walled City, and focuses on spatial practices that contest the established notions regarding the infrastructure of partition, with special attention to the Buffer Zone. The analysis, based on qualitative data collected on field, is centered on the actions and activities of NGOs and radicalized groups, in order to explore some of the socio-spatial processes through which diverse groups of people come together and negotiate their understanding of belonging, thus renegotiating, in this context, notions of identity, citizenship, and memory. I argue that Nicosia's Buffer Zone is a dynamic social construction; and as such it induces various interpretations and discourses, while it simultaneously provides the space for their physical expression. In conclusion, this space is being transformed, even briefly, into shared space, produced by the combined efforts of civil society. This paper aims at highlighting this rarely acknowledged perspective of space production under contested state.

\section{Introduction}

"I believe that the idea of the totality, the finality of the master-plan, is misguided. One should advocate a gradual transformation of public space,

${ }^{*} \mathrm{PhD}$ Candidate, Institute for European Urbanism, Bauhaus University Weimar, Germany. 
a metamorphic process, without relying on a hypothetical time in the future when everything will be perfect." (Libeskind, 1995)

These are the words of architect Daniel Libeskind, when in 1995 he was writing about the transformation of Alexanderplatz in post-unification Berlin. In an era of construction and redesign frenzy in post-Cold War Germany, he fervently argued for a new interpretation of urban planning and the master-plan as a tool away from a holistic approach, and against the separate addressing of urban from social and political problems. Albeit in a significantly different political and social context, his words arguing for a "full participatory process" that involves the citizens are highly relevant for many cities today, including the case study this paper is concerned with, Nicosia.

Nicosia, the capital of Cyprus, has been a divided city officially since 1974. Cyprus is a relatively small island of $9.250 \mathrm{~km}^{2}$, located in the eastern part of the Mediterranean basin, and populated by two large ethnically diverse groups: Greek-Cypriots and Turkish-Cypriots. It is one of these places with long and mostly troubled history that present certain difficulties in recounting their stories. Each era seems to bear deep marks carved by its predecessor on the island's landscape. In a unique geostrategic position, Cyprus has stood on the verge, between West and East, between occident and orient, at times struggling with, at times enjoying the traits of both. Over the centuries, Nicosia has served as the seat of power for the Venetians, the Ottomans, the British, and eventually the Republic of Cyprus, when it was declared an independent state in 1960.

Growing inter-communal violence between Greek- and Turkish-Cypriots through the $60 \mathrm{~s}$ brought on the Turkish invasion of the northern part of the island in 1974, and resulted in extensive displacement of populations, and a sub-division of both island and capital city into two, with each part absorbed into a separate political entity. Southern Nicosia continued being the capital of the Republic of Cyprus, while northern Nicosia eventually became capital of the Turkish Republic of Northern Cyprus, a self-declared state recognized only by Turkey. The border between the two political entities is a Buffer Zone established by the United Nations during the 1963 hostilities as a cease fire zone, also known as the Green Line. It stretches for $185 \mathrm{~km}$ from west to east with a width that ranges from $7.4 \mathrm{~km}$ in some rural areas to only 3.3 meters in the centre of Nicosia's Walled City, where it takes up about $10 \%$ of its area (Hadjipavlou, 2007; Constantinou \& Papadakis, 2001). The Buffer Zone, maintained and patrolled until today by the United Nations Peacekeeping Force in Cyprus (UNFICYP), is equipped with outposts of Greek- and TurkishCypriot militia on each respective side. Until 2003, it has been an impermeable border; moving from south to north and vice versa was prohibited, and interaction between Greek- and Turkish-Cypriots was effectively precluded for a generation. 
Since 1974 there have been many failed attempts to resolve the political issue known as the Cyprus Problem ${ }^{1}$; the most recent one being the 2004 Annan Plan. While $65 \%$ of Turkish-Cypriots favored it in a referendum, a vast majority of $76 \%$ of Greek-Cypriots opposed the plan that would have brought both sides of the island into the European Union together (Pericleous, 2009). This outcome stroke a heavy blow at the bi-communal movement that started developing throughout the 1990s and was at a height after the unexpected opening of the crossings in 2003. In May 2004, the Greek-Cypriot side of Cyprus became a member of the European Union as a de jure whole polity but a half territory ${ }^{2}$. As a result, the UN Buffer Zone became the easternmost border of the EU, and Nicosia the divided capital of an EU country. Within this altered framework, peace talks were resumed in 2008, and they are at the time of writing still ongoing.

Hence, Nicosia is still in physical, governance and military terms a divided city. The physical partition of a city is considered a discord and a nonsustainable long-term solution (Calame \& Charlesworth, 2009; Bollens, 2001). It's a situation imposed as an emergency measure against inter-communal violence, intending to be temporary but instead turning permanent. In most cases, a political settlement is considered a prerequisite before revitalization or cooperative development. In cases like Nicosia however, where this political consensus is stalled, the partition becomes part of the city and urban life.

This paper is critically looking at the integration of partition into urban life, as well as the actions of resistance against it. The main focus is on Nicosia's Walled City and the spatial transformations of the UN controlled Buffer Zone bisecting it, through spatial practices that contest the established notions regarding the infrastructure of partition. This paper consists of 4 parts: the first part explores the origins of partition, and offers an overview of Nicosia's spatial particularities, followed in the second part by a short analysis of the official planning strategy established by the bi-communal Nicosia Master Plan. The third part is concerned with the actions and activities of two local initiatives in Nicosia, the Home for Cooperation (H4C) and the shortlived Occupy Buffer Zone movement (OBZ), while the fourth part summarizes the main conclusions. The analysis is based on qualitative data collected on field, aiming at exploring some of the socio-spatial processes through which diverse groups of people, NGOs and radicalized groups, come together and negotiate their understanding of belonging in the context of a divided city.

\footnotetext{
${ }^{1}$ For more details on the Cyprus Problem, and a critical appraisal to the Cyprus peace talks see Kyle (1997) and Michael (2007) respectively.

${ }^{2}$ In 2002, the EU summit in Copenhagen invited Cyprus to join EU in 2004 provided the two communities agree to UN plan by early spring 2003. Without reunification, only the internationally recognized Greek Cypriot part of the island would gain membership (BBC News, 2011) http://news.bbc.co.uk/2/hi/europe/1021835.stm (accessed 22 July 2014).
} 


\section{A Divided City with Particular Spatial Conditions}

The origins of partition in Nicosia lay in Cyprus's colonial past (1878 1960) and its people's struggles against British imperialism long before dividing lines were drawn and consolidated. During the colonial time, the two communities, although not physically separated, were subjects to separate administrations, resulting in distinct educational systems that were perpetuating ethnic differences (Dietzel \& Makrides, 2009; Given, 2002). The GreekCypriot desire for Enosis (Union) with Greece was actively pursued with an anti-colonial movement between 1955 and 1959, causing distress and fear to the island's Turkish minority, who in the prospect of their future as Greek subjects promoted the option of Taksim (Partition). Armed conflict between paramilitaries was soon to erupt, leading to a response from the British to separate the two communities into ethnic enclaves in Nicosia in order to lessen the violence. A barbed-wire fence called the 'Mason-Dixon Line' divided Nicosia's Walled City, and was a precursor to the Green Line established by the UN in 1963 (Mallinson, 2008; Pollis, 1973; Tzermias, 2000).

Cypriot strife for self-determination entangled with social fights and rapid urbanization gave birth to a fragile independent state (Republic of Cyprus) in $1960^{1}$, contested around competing nationalisms. The newborn Republic was bestowed an unalterable constitution, assigning equal veto power to the two communities, thus essentially immobilizing the government (Tzermias, 2000; Papadakis, 2005; Papadakis, Peristianis, \& Welz, 2006). Cyprus was a binational state on paper, but the social realities on the ground differed substantially. In 1963, tension escalated to open violence initiating an 11-yearslong conflict, during which most Turkish-Cypriots were forced by both Greekand Turkish-Cypriot paramilitaries to gather in enclaves ${ }^{2}$, where they faced difficult times, especially after a blockade limiting the delivery of food and supplies. Therefore, Nicosia's partition was practically in effect since 1956; it only became permanent in 1974 with the Turkish invasion and the establishment of an impermeable border between the two communities.

In the aftermath of the conflict, two official narratives have been consolidated; the dividing Buffer Zone being central to both, as it has acquired an exceptional place in Cypriot imagination. These national narratives have been constructed in a self-validating way, as each side sees their own as victims and the 'other' as perpetrator, forming heterogeneous memories of the same events, and renouncing guilt and responsibility. For Greek-Cypriots, Cyprus was a peaceful island inhabited by two peoples who could live, work and prosper together until the day of the Turkish invasion in 1974. The Buffer Zone represents a brutal line of separation, the constant reminder of territories, people and homes lost to conflict (Demetriou, 2005; Dikomitis, 2005; Kliot \&

\footnotetext{
${ }^{1}$ Cyprus gained independence in 1960 after diplomatic negotiations amongst Greece, Turkey, and the United Kingdom resulted in the Treaty of Guarantee. This treaty gave the three guarantors the right to intervene in case the islands' independence is threatened (BBC News, 2011) http://news.bbc.co.uk/2/hi/europe/1021835.stm (accessed 22 July 2014).

${ }^{2}$ The largest of these enclaves was the northern part of Nicosia (Hadjipavlou, 2007).
} 
Mansfield, 1997). The Turkish-Cypriot narrative stresses the suffering of an endangered oppressed minority under Greek-Cypriot rule (Navaro-Yashin, 2012). For them, the crucial date is 1963, while 1974 and the consequent partition is celebrated as liberation. The Buffer Zone in this narrative is a line of protection and safety from the 'other', who cannot be trusted (Kliot \& Mansfield, 1997; Papadakis, Peristianis, \& Welz, 2006; Papadakis, 2006).

Hence, the Buffer Zone has acquired the status of a symbol for both communities, accentuated by the fact that it had remained inaccessible. The symbolism and significance of the Buffer Zone are integrated in current realities as this space has come to embody the various understandings of the 'Cyprus conflict'. The two polities have capitalized on its importance, employing the mechanism of emergency to exercise power, creating emotional and political dependence on the division (Demetriou, 2006; Navaro-Yashin, 2012). Post-war identification was thus constructed around the existence of division, the knot that holds together various conceptualizations of what it means to be a Cypriot on either side of the divide. Moreover, division has not only been internalized, but also normalized as a way of living in the postconflict period (Demetriou, 2012; Hatay \& Bryant, 2008).

Nicosia's Walled City is the place in Cyprus where the divide has been an everyday experience, and one of the urban areas most affected by the situation of partition. Redesigned by the Venetians in the shape of a perfect circle, the Walled City stands today brutally cut in two: streets and alleys leading to dead ends and barricades, neighborhoods deprived of their most vital parts, the vibrant part of the city, its market in Ermou Street, falling within the Buffer Zone. The historic city center has turned into two edges, gradually abandoned by its old inhabitants, rendered unattractive and for many years considered dangerous.

The nature of the partition per se, as described above, is one of the particular spatial conditions Nicosia is presenting. A second particularity is the establishment of Nicosia Master Plan soon after 1974, to specifically address the deterioration and depopulation of the Walled City. The third particularity, which signifies a shift of paradigm in Cyprus, is the restitution of mobility between south and north in 2003, when the impenetrable border suddenly opened $^{1}$ and crossing was allowed by providing one's passport. This change was welcomed by most Cypriots, who hurried to see the 'other side'. The opening of the crossings meant the possibility for casual effortless interaction between two communities living officially apart for, at that time, almost 30 years (Demetriou, 2007; Hadjipavlou, 2007). Today, eleven years later, there are seven active checkpoints for crossing; two of them are located in Nicosia, one solely pedestrian (the Ledra Street/ Lokmaci crossing) at the city center. The Walled City remains the sole urban area in Cyprus where this change is

\footnotetext{
${ }^{1}$ Between 2000 and 2003 massive demonstrations took place in the north, demanding the end of their spatial isolation and resulting in the opening of the crossings. This changed not only the power balance there but also the ways in which Turkish-Cypriots were portrayed by the media in the south: not as the perpetrators of violence but as the oppressed victims of their regime (Demetriou, 2007).
} 
experienced as part of a daily routine. This provided a unique chance for the formation of new local initiatives. I argue that the restitution of mobility has challenged the ways in which people in Nicosia relate to the Buffer Zone and construct their urban experience in this context.

\section{The Nicosia Master Plan}

As already mentioned, soon after the official partition, a planning body was established in Nicosia. It was the bi-communal Nicosia Master Plan, initiated in 1979 under the auspices of the United Nations Development Program (UNDP) primarily to address the practical issue of an incomplete sewage system. A mixed team consisting of Greek- and Turkish-Cypriot architects, planners, sociologists, engineers and foreign advisors was formed, and with the help and guidance of Nicosia's two municipal leaders worked effectively together in various projects. This initiative was the first (and for some time the only) common project carried out by the two communities (Stratis, 2010).

The Master Plan was conceived as a framework that would guide and set out the overall planning strategy for Nicosia, ensuring the rational development of the city's two parts and preparing the ground for reunification (Hadjichristos, 2006). It was hence established under the light of a solution soon to come, at which point the city's problems could be addressed in their entirety. Over the years there have been different projects running simultaneously, following, and physically implementing its guidelines. The NMP projects were addressing planning, architectural, economic, environmental, and social problems caused or accentuated by the divide; the depopulation of the Walled City, the transformation and continuous degradation of this urban area, the loss of centrality, a general lack of civic space, a general unwillingness to invest, and the decline of vitality being only the overarching ones (Nicosia Master Plan Final Report, 1984)

According to a diagnostic analysis carried out in 2004, NMP interventions, despite their local success, "have not contributed sufficiently to an overall regeneration outcome" (Constantinides \& Ozen, 2004, p. 8). The NMP projects have had considerable success, but only in physical terms ${ }^{1}$, stimulating small scale activities and pockets of high quality residential development ${ }^{2}$. Once an innovative approach towards planning under contested state, the Master Plan that became famous for its success in bypassing the political deadlock does not meet current needs, reflected especially in the Walled City's changing demographics ${ }^{3}$. The diagnostic analysis emphasized that the "continuing

\footnotetext{
${ }^{1}$ Demetriou (2006) is referring to this as structural reunification, but argues that Nicosia remains divided in other senses than infrastructure, poverty in the north compared to the south being an important point.

${ }^{2}$ The revitalization projects in the neighborhoods of Arab Ahmet in the north and Chrysaliniotissa in the south are prominent (Nicosia Master Plan Bi-communal Team , 2005).

${ }^{3}$ The Walled City has been gradually abandoned during the 40-year-partition. Despite the success of the Master Plan rehabilitation projects, few of the old inhabitants have been keen on
} 
division is central to the persistence of Nicosia's problems, and the impacts of public policies have been limited in mitigating this process" (Constantinides \& Ozen, 2004, p. 5).

Although in relevant literature (Charlesworth, 2006; Harvey, 2012; Gaffikin, Sterrett, McEldowney, Morrissey, \& Hardy, 2008), scholars are supporting the idea that planners and architects should take immediate action after the end of the conflict even before official settlement is reached, Nicosia, emphasized as a positive such example, is challenging the role and responsibility of professionals yet again.

Despite the relevance of urban planning as an instrument in conflict resolution, questioning the boundaries of its capability in facilitating 'integrative cityscapes' or 'shared space' ${ }^{1}$, brings forth another aspect: if the top-down approach of a master-plan is failing, what other agencies and actors are at play?

\section{Local Initiatives}

The concept of 'shared', 'shared space', 'shared city', includes in its basic interpretation a collaboration across the divide that can lead to integrated living (Gaffikin, Mceldowny, \& Sterrett, 2010). However, it involves spatial and temporal parameters as well: who, when and where is seeking interaction?

\section{Home for Co-Operation}

In the 2006 CIVICUS Civil Society Index, Cypriot civil society is described as "fragmented and less than efficient", with limited cooperation between Greek- and Turkish-Cypriot civil society organizations, and moderate impact in the south and even lower in the north (Lönnqvist, 2008). The bicommunal movement in Cyprus started forming and growing slowly during the 1990s. Until 2003, bi-communal activities were engaged in by a small part of the society in both south and north, not only due to prejudice and distrust, but also because of discouragement facilitated by the authorities through various regulatory factors, including special authorization to cross (into) the Buffer Zone. Bi-communal meetings and workshops were facilitated by external agencies (national governments, the United Nations Development Programme,

moving back, preferring instead more popular areas in other parts of the city away from the Buffer Zone. The Walled City is nowadays populated mostly by migrants: from Turkey in the north $(80 \%)$ and from countries in Asia, Africa and Eastern Europe in the south (55\%) (Nicosia City Profile) http://www.conflictincities.org/Nicosia.html (accessed 22 July 2014).

${ }^{1}$ The term 'integrative cityscapes' is used in Gaffikin, Mceldowny, \& Sterrett (2010). From this point onwards I use the term 'shared space' instead, based on my understanding of space and its production.

${ }^{2}$ In my work, space is generally considered a product of various spatial practices, either official or unofficial, deriving from an established understanding of the notion of the 'urban'. The term 'urban' here was initially used to denote the characteristics of (living in) the city, or city life in contrast to rural life. It was soon expanded to also include the social structures that are manifesting in the city, the civic. 
the Fulbright Commission, later the European Union) and held in the Buffer Zone which was deemed neutral ground (hotel Ledra Palace, mixed village of Pyla, or abroad (Broome, 2005; Vogel \& Richmond, 2013). Main goal for the participants of these events was simply to meet, interact with the 'other' in order to understand their hopes and fears, and construct a relationship of trust. This functioned primarily on a personal level through informal networking of interested individuals, who would in due process be the foundation of reconciliation after a political solution is reached (Broome, 2004; Port, 2005).

The 2003 re-establishment of mobility signified for them the end of an era, raising their hopes for reunification, while forcing them to rethink their agendas since casual effortless interaction between peoples was at last a reality [Demetriou, personal communication 2013; Hatay, personal communication 2013].

While analyzing the Buffer Zone as a social construction through secondary sources and concurrent fieldwork, I started exploring the possibility that the Walled City and the Buffer Zone specifically is also where people in Nicosia come together and negotiate their understanding of being divided in an urban context. My fieldwork revealed a still small but vibrant civil society active not only with reference to but inside the Buffer Zone. Moreover, the Buffer Zone space is where both emerging official ${ }^{1}$ as well as unofficial practices relate to, often intersecting, even colliding. As political elites remained idle after the opening of the crossings and the Republic's accession to the EU, bi-communal local initiatives have been struggling to come forth and bring about the changes they aspire to.

Such an initiative is the Association for Historical Dialogue and Research, founded in 2003, now an esteemed NGO working towards enhancing dialogue on history education, supported by teacher trade unions on both sides of the divide (Epaminondas, 2011). This organization mobilized external resources to found in 2011 the Home for Cooperation (H4C). After a long struggle with bureaucracy and paperwork, a building inside the Buffer Zone was purchased, restored, and turned into operational headquarters, where office and meeting space is offered to other NGOs now developing around it. Today, H4C stands at the heart of institutionalized activism; NGOs are raising funds and organizing a range of events and actions (language courses, conferences on relevant subjects, movie screenings, talks, a Critical History Archive) promoting cooperation and peace. This space in the Buffer Zone at the periphery of the Walled City serves as a sanctuary for the members of the bicommunal movement. With the crossings open, this characterized as neutral space facilitates interaction, and bringing people in the Buffer Zone is

\footnotetext{
${ }^{1}$ In 2012, the Greek-Cypriot Nicosia municipality placed a bid for becoming Cultural Capital of Europe. The campaign was structured around a concept of entering and changing the Buffer Zone with a wide range of activities organized in the Greek-Cypriot side. Although main axis of the argumentation was that Nicosia is the city that promotes peace, this initiative significantly lacked Turkish-Cypriot involvement and participation. The multifaceted criticism of this campaign, although interesting, lies outside the scope of the current paper.
} 
transforming this space into a bridge, a space of connection instead of a space of division.

However, criticism coming from within this civil society emphasizes the still limited outreach to the wider public. Involved interviewees ${ }^{1}$ expressed their concern that the bi-communal movement is becoming self-congratulatory, with the same groups of people organizing and attending the events. $\mathrm{H} 4 \mathrm{C}$ has evolved into a home of bi-communalism, a space safe for its users, characterized by (also architectural) privateness (as opposed to publicness), which allows their ideas to grow and mature but obstructs their communalization, their opening to the wider Cypriot publics. Initiatives are limited in the Buffer Zone, which despite the restored mobility, still functions as a border between communities, in spatial, political, and social terms.

\section{Occupy Movement}

It is in this context, that the emergence of an Occupy movement in Nicosia, known as Occupy Buffer Zone (OBZ), should be contemplated. Following the rise of similar movements worldwide, this grassroots initiative lasted 8 months (October 2011 - May 2012); it was not, however, purposefully formed as a movement from the beginning. According to interviewed participants $^{2}$, it developed gradually as a form of protest against social inequalities and constructed local marginalities, part and parcel of the Cypriot realities on both sides of the divide, as well as against the continuous militarization of the island. Its core, a radical group consisting of leftists/antiauthoritarian students, academics, artists, and activists was already active in the Walled City, in the quite central square of Phaneromeni Church (one of the few open public spaces in Nicosia's Walled City). Although, there was a common consensus amongst the group that collaboration and symbiosis shape the future they want, their actions were addressing a wider range of social issues exacerbated by the then incipient, now advancing, gentrification. Even more important is that the movement did not define itself as a unification movement, yet, it found physical manifestation inside the Buffer Zone at the most central point of Walled Nicosia, the Ledra Street/Lokmaci crossing. It was the first time in 40 years of official division that people from both sides of the divide were able to have unmediated, also unauthorized, access to the Buffer Zone.

In Ledra Street/ Lokmaci crossing, there is between Greek- and TurkishCypriot control spots a narrow 50 meters long space. On a busy day in central Nicosia, this is a distance hundreds of people walk to reach the other side. The OBZ participants proved by camping there, thus physically reclaiming for a non-military purpose part of the Buffer Zone, that shared space was possible. In the 8 months of its duration OBZ hosted a variety of activities, discussions, movie screenings and workshops open to everyone. Such an unprecedented action caused discomfort to Greek- and Turkish-Cypriot authorities, and baffled the UNFICYP in the lack of jurisdiction over this space, and the simultaneous absence of a legal framework to evict the occupiers. Only when

\footnotetext{
${ }^{1}$ The informants prefer to remain anonymous [personal communication 2013].

${ }^{2}$ The informants prefer to remain anonymous [personal communication 2013].
} 
one was established, after the OBZ occupied a nearby empty building, became possible for the antiterrorist squad of the Greek-Cypriot police to forcibly remove the participants (Ilican, 2013).

The limited attention by local media and the lack of significant supportive response by the public were discouraging. Alleged associations with unlawful activities and the denigration of the movement's political standpoint and vision further delegitimized OBZ after its dissolution (Ilican, 2013). Cyprus conflict is predominantly about sovereignty. Space (land, territory, property) is an intrinsic component of this dispute, and any claim over it is bound to face the wall of local politics. This Occupy movement challenged the established norm in a very real tangible way by literally setting foot on a disputed territory. Thus, to quote M. E. Ilican (2013), "performed sovereignty" and this trait differentiated it from other Occupy movements. To take this statement further, I argue that OBZ performed at the same time unification and the utopian polity where this was possible. The participants, protesting against their respective societies and seeking bottom-up change, created in-between polities the civic space for dialogue direly missing from Nicosia. I argue that far from simply needing a physical space, it was the qualities they imagined and vested in the Buffer Zone space that transformed this piece of land into their ideal polity, a shared civic space. Through their spatial practices in Ledra Street/Lokmaci crossing they did not only use or occupy space in the Buffer Zone, but also transformed the space, even briefly, by ascribing new meanings, hence producing in this very locality a new - at last peaceful - place to 'inhabit'.

\section{Conclusion}

Conflict, ethno-national and social alike, has spatial expression. Conversely, spatial transformations can also affect conflict resolution processes, testifying to the important role of urban planning as a tool (Byrne, 2012; Stanley-Price, 2005). Nonetheless essential, top-down planning is not a remedy for all problems. It is necessary to have publics informed and sensitized enough to demand, reclaim and even fight for their right over space. In other words, civic awareness is a key factor that can and should be mobilized in participatory planning processes.

However, conflict is not inherent in societies. Urban partition, rather than being simply a result of escalation of conflict between opposing parties, is also a symptom of social pathogenesis. According to Calame and Charlesworth (2009), every city is established upon an 'urban contract' between the citizens and the city's government according to which the citizens offer services in exchange for "positive conditions favoring development", social opportunities and safety. When the city's managers, hence the city, fail to fulfill these conditions, the part of society that feels threatened, assumes control, and violence is likely to erupt. Walls are then considered a 'quick fix' to lessen the violence. In this sense partition is a symptom of severe social breakdown. 
In their writings on contested cities ${ }^{1}$ and the concept of public space F. Gaffikin et al. (Gaffikin, Mceldowny, \& Sterrett, 2010; Gaffikin, Sterrett, McEldowney, Morrissey, \& Hardy, 2008) interrogate the role of urban planning in facilitating integrative cityscapes. In their work, they differentiate between cities contested around issues of pluralism and those contested around sovereignty as well, arguing that in the later case all other issues, however existing, are subordinated to the major dispute: the competing nationalisms and their territorial claims. Here lies a key issue for Nicosia's current realities. In the face of the omnipresent danger of a never-ending conflict, other discussions and contestations within Cypriot societies have been gagged by the state (RoC and TRNC), and in the case of the Greek-Cypriots eventually ignored by the majority of the public.

A wide range of issues (from peace and demilitarization, to migrant rights, human rights, press censorship and discrimination, and from women's rights and social inequalities to history education and rising unemployment) have been systematically ignored by the authorities on both sides of the divide, and summarily swept under the carpet; they are only to be addressed after the major dispute is resolved (Demetriou, 2012). Deferring the solution of current issues to an unknown future time seems to have seized resonating with large part of the civil society. The need for these debates is slowly becoming increasingly pressing. As grassroots urban movements are at a height around the world, the ground seems to be fertile for a blossoming of debates in Cypriot society as well ${ }^{2}$.

To summarize, the overarching dispute has served as a veil for underlying social issues. As the 2004 diagnostic analysis demonstrated, their close relation to the Walled City's spatial problems has not been adequately addressed by the Nicosia Master Plan. Looking at the most prominent implication of partition, however, the essentially untouched by the $\mathrm{NMP}^{3}$ Buffer Zone, I saw beyond a dead zone; a space the city's civil society has in various ways reclaimed, when faced with prolonged partition, unregulated gentrification and their unanswered needs.

The liberal and radical forces (represented by $\mathrm{H} 4 \mathrm{C}$ and OBZ) active in Nicosia have developed comparable spatial practices to pursue their goals, using different resources and mobilizing different crowds to reclaim parts of the Buffer Zone space. Not unlike OBZ, AHDR created its own Home (for Cooperation) to serve the needs of a developing network of Cypriot NGOs. However restricted the use of $\mathrm{H} 4 \mathrm{C}$ might be by its supporters' agendas, its resources and benefactors, and various agreements with the RoC government, the Turkish Cypriot administration and the UN, the aims of the two to great

\footnotetext{
'Often in literature, the terms 'divided city' and 'contested city' are used interchangeably. For the purposes of this research, a divided city is defined as one primarily contested around issues of sovereignty with a severe physical separation of its urban fabric as a result of urban conflict and violence.

${ }^{2}$ This, due to differing circumstances, seems to have happened earlier in the Turkish Cypriot side (Demetriou, 2012).

${ }^{3}$ The first survey of buildings within Nicosia's Buffer Zone was conducted by Nicosia Master Plan between 2001 and 2004.
} 
extend overlap. To decipher their actions, I have argued the archetypical architectural binary: publicness vs. privateness, with one initiative, the $\mathrm{H} 4 \mathrm{C}$, representing a perceived ${ }^{1}$ introverted behavior, and the other, the OBZ, a perceived extroverted behavior dominating their spatial practices. Their effectiveness and resonance with the wider publics aside, these two initiatives have demonstrated the Buffer Zone's potential to be reclaimed, its meaning renegotiated. Notwithstanding the peril of limiting this potential within the narrow space between two polities, the Buffer Zone offers the possibility for writing a new script, shifting the focus away from the efforts to overcome the ethno-national divide, towards constructing and realizing a common understanding of shared space.

In many aspects, divided Nicosia is stuck in a spatial and temporal limbo awaiting a political solution to the Cyprus problem. However, its two parts have been also multifariously changing. Within this context, shared space cannot be postponed to "a hypothetical time in the future when everything will be perfect". Nicosia's Buffer Zone, far from being only a militarized piece of land between opposing sides, has been transformed through spatial practices, transforming along the peoples' lived experience of the city, the ways they relate to past experience, as well as the ways they imagine future urban experience, and how they articulate and pursue the realization of these imageries today.

\section{References}

BBC News. (2011, December 13). Cyprus profile. Retrieved from http://news.bbc.co. uk/2/hi/europe/1021835.stm

Bollens, S. A. (2001). City and soul Sarajevo, Johannesburg, Jerusalem,. City, 5(2), 169-187.

Broome, B. (2004). Reaching across the Dividing Line: Building a Collective Vision for Peace in Cyprus. Journal of Peace Research, 41(2), 191-209. Retrieved from http://www.jstor.org/stable/4149594

Broome, B. (2005). A Guide to Intercultural Communication in Cyprus . Nicosia: United Nations Development Programme .

Byrne, J. (2012). Belfast and beyond: Local and international narrative of physical segregation. Shared Space, 12, 5-22.

Calame, J., \& Charlesworth, E. (2009). Divided Cities Belfast, Beirut, Jerusalem, Mostar, and Nicosia. Philadelphia: University of Pennsylvania Press.

Calame, J., \& Charlesworth, E. (n.d.). The Divided City as Broken Artifact.

Charlesworth, E. (2006). Architects Without Frontiers War, Reconstruction and Design Responsibility. Oxford: Elsevier Ltd.

Constantinides, G., \& Ozen, G. (2004). Nicosia Master Plan New Vision for the Core of Nicosia - Final Report. Nicosia: United Nations Development Programme.

Constantinou, C. M., \& Hatay, M. (2010). Cyprus, ethnic conflict and conflicted heritage. Ethnic and Racial Studies, 33(9), 1600-1619.

\footnotetext{
${ }^{1}$ This is the researcher's assessment with regard to the perception of the spatial practices of these two local initiatives, based on fieldwork. It may differ from the participants' expressed intentions, as well as public opinion in various levels.
} 
Constantinou, C., \& Papadakis, Y. (2001). The Cypriot State(s) in situ: Cross-ethnic Contact and the Discourse of Recognition. Global Society, 15(2), 125-148.

Demetriou, O. (2005, June). EU and the Cyprus Conflict. Working Papers Series in EU Border Conflicts Studies. Perceptions of the border and Europe in the Cyprus conflict.

Demetriou, O. (2006). Freedom Square: The unspoken reunification of a divided city. HAGAR: Studies in Culture, Polity \& Identities, 7(1), 55-77.

Demetriou, O. (2007). To Cross or Not to Cross? Subjectivization and the Absent State in Cyprus. The Journal of the Royal Anthropological Institute, 13(4), 9871006.

Demetriou, O. (2012). The Militarization of Opulence. International Feminist Journal of Politics, 14(1), 56-77.

Dietzel, I., \& Makrides, V. N. (2009). Ethno-Religious Coexistence and Plurality in Cyprus under British Rule (1878-1960). Social Compass, 56(1), 69-83.

Dikomitis, L. (2005, October). Three Readings of a Border: Greek Cypriots Crossing the Green Line in Cyprus. Anthropology Today, 21(5), 7-12.

Epaminondas, M. (2011). The Home for Cooperation (H4C). Nicosia: K\&L Lithofit Ltd.

Gaffikin, F., Mceldowny, M., \& Sterrett, K. (2010). Creating Shared Public Space in the Contested City: The Role of Urban Design. Journal of Urban Design, 15(4), 493-513.

Gaffikin, F., Sterrett, K., McEldowney, M., Morrissey, M., \& Hardy, M. (2008). Planning Shared Space For A Shared Future A Research Report for Community Relations Council. Belfast: Community Relations Council.

Given, M. (2002, March). Maps, Fields, and Boundary Cairns: Demarcation and Resistance in Colonial Cyprus. International Journal of Historical Archaeology, 6(1).

Groth, J., \& Corijn, E. (2005, March). Reclaiming Urbanity: Indeterminate Spaces, Informal Actors and Urban Agenda Setting. Urban Studies, 42(3), 503-526.

Hadjichristos, C. (2006). Cyprus: Nicosia and its d-Visions. Architectural Design, 76(3), 12-19.

Hadjipavlou, M. (2007). Multiple stories: The "crossings" as part of citizens' reconciliation efforts in Cyprus? Innovation, 20(1), 53-73.

Hadjipavlou, M. (2007, May). The Cyprus Conflict: Root Causes and Implications for Peacebuilding. Journal of Peace Research, 44(3), 349-365. Retrieved from http://www.jstor.org/stable/27640515 .

Harvey, D. C. (2012). Book Review Divided Cities: Belfast, Beirut, Jerusalem, Mostar, and Nicosia By Jon Calame and Esther Charlesworth. Societies Without Borders, 7(3), 380-384.

Hatay, M., \& Bryant, R. (2008). The Jasmine Scent of Nicosia: Of Returns, Revolutions, and the Longing for Forbidden Pasts. Journal of Modern Greek Studies, 423-449.

Ilican, M. E. (2013). The Occupy Buffer Zone Movement: Radicalism and Sovereignty in Cyprus. Cyprus Review, 25(1), 55-79.

Kanol, B., \& Direnç, K. (2013). Roadblocks to Peacebuilding Activities in Cyprus: International Peacebuilding Actors' Handling of the Recognition Issue. Journal of Conflictology, 4(2), 39-47. doi:http://dx.doi.org/10.7238/joc.v4i2.1828

Kliot, N., \& Mansfield, Y. (1997). The political landscape of partition: The Case of Cyprus. Political Geography, 16(6), 495-521.

Kyle, K. (1997). Cyprus: In Search of Peace. Minority Rights Group International. 
Landzelius, M. (2003). Commemorative dis(re)membering: erasing heritage, spatializing disinheritance. Environment and Planning D: Society and Space, 21, 195-221.

Lehtovuori, P. (2011). Towards Experiential Urbanism. Critical Sociology, 38(1), 71 87.

Libeskind, D. (1995). Berlin Alexanderplatz: Ideologies of Design and Planning and the Fate of Public Space. The Journal of the International Institute, 3(1). Retrieved from http://hdl.handle.net/2027/spo.4750978.0003.101

Lönnqvist, L. (2008, October). Civil society in reconciliation: beyond the 'Cyprus problem'. POLICY BRIEFING PAPER 21. International NGO Training and Research Centre.

Mallinson, W. (2008). Cyprus A Historical Overview.

Michael, M. S. (2007, September). The Cyprus Peace Talks: A Critical Appraisal. Journal of Peace Research, 44(5), 587-604. Retrieved from http:/www. jstor.org/stable/27640568

Navaro-Yashin, Y. (2012). The Make-Believe Space: Affective Geography in a Postwar Polity. Durham: Duke University Press.

Newman, D. (2005). World Society, Globalization and a Borderless World The Contemporary Significance of Borders and Territory. World Society Focus Paper Series. (Z. World Society Foundation, Ed.)

Newman, D. (2006). Borders and Bordering Towards an Interdisciplinary Dialogue. European Journal of Social Theory, 9(2), European Journal of Social Theory.

Newman, D. (2006). The lines that continue to separate us: borders in our 'borderless' world. Progress in Human Geography, 30(2), 143-161.

Nicosia City Profile. (n.d.). Retrieved from Conflict in Cities and the Contested State: http://www.conflictincities.org/Nicosia.html

Nicosia Master Plan Bi-communal Team . (2005). Walled Nicosia: A Guide to its Historical and Cultural Sites. Nicosia Master Plan.

Nicosia Master Plan Final Report. (1984). Nicosia: UNDP UNCHS (HABITAT).

Papadakis, Y. (2005). Echoes from the Dead Zone Across the Cyprus Divide. London: I.B. Tauris \& Co Ltd.

Papadakis, Y. (2006). Nicosia after 1960: A River, A Bridge and a Dead Zone. Global Media Journal: Mediterranean Edition, 1(1), 1-16.

Papadakis, Y., Peristianis, N., \& Welz, G. (2006). Divided Cyprus Modernity, History, and an Island in Conflict. Bloomington: Indiana University Press.

Pedrazzini, Y., Bolay, J.-C., \& Kaufmann, V. (2005). Social practices and spatial changes. NCCR North-South Dialogue.

Pericleous, C. (2009). The Cyprus Referendum. A Divided Island and the Challenge of the Annan Plan. London: I.B.Tauris \& Co Ltd.

Pollis, A. (1973, July). Intergroup Conflict and British Colonial Policy: The Case of Cyprus. Comparative Politics, 5(4), 575-599.

Port, S. R. (2005). The Inter-Communal Relations Among NGOs Operating With Cyprus. Independent Study Project (ISP) Collection. Retrieved from http://digitalcollections.sit.edu/isp_collection/478

Stanley-Price, N. (Ed.). (2005). Cultural Heritage in Postwar Recovery. Rome: ICCROM.

Stratis, S. (2010). Collective Masterplan. Bauwelt.

Tzermias, P. (2000). History of the Republic of Cyprus vol. 1. Athens: Libro.

Vogel, B. (2011, November). Preliminary field work report from Cyprus. CORE Working Paper. Cultures of Governance and Conflict Resolution in Europe and India. 
Vogel, B., \& Richmond, O. (2013). Enabling civil society in conflict resolution. Recommendations for international donors on their relationship to Cyprus's intercommunal movement. CORE Policy Brief. Cultures of Governance and Conflict Resolution in Europe and India. 
